Applied Physiology, Nutrition, and Metabolism Physiologie appliquée, nutrition et métabolisme

\title{
Human Rights at Work: Physical Standards for Employment and Human Rights Law
}

\begin{tabular}{|r|l|}
\hline Journal: & Applied Physiology, Nutrition, and Metabolism \\
\hline Manuscript ID & apnm-2015-0552.R2 \\
\hline Manuscript Type: & Review \\
\hline Date Submitted by the Author: & 22-Feb-2016 \\
\hline Complete List of Authors: & Adams, Eric; University of Alberta, Faculty of Law \\
\hline Keyword: & physiological assessment of performance < performance \\
\hline
\end{tabular}

\section{SCHOLARONE \\ Manuscripts}


Human Rights at Work: Physical Standards for Employment and Human Rights Law

Eric M. Adams

Associate Professor of Law

University of Alberta, Faculty of Law

eric.adams@ualberta.ca 


\begin{abstract}
This article focuses on the human rights dimensions of creating and implementing physical standards for employment for prospective and incumbent employees. The article argues that physical standards for employment engage two fundamental legal concepts of employment law: freedom of contract and workplace human rights. While the former promotes an employer's right to set workplace standards and make decisions of whom to hire and terminate, the latter prevents employers from discriminating against individuals contrary to human rights legislation. With reference to applicable human rights legislative regimes and their judicial interpretation in Canada, the United States, the United Kingdom, and Australia this article demonstrates the judicial preference for criterion validation in testing mechanisms in the finding of bona fide occupational requirements. With particular attention to the Supreme Court of Canada decision in Meiorin, this article argues that an effective balance between workplace safety and human rights concerns can be found, not in applying different standards to different groups of individuals, but in an approach that holds employers to demonstrating a sufficient connection between a uniform physical standard of employment and the actual minimum requirements to perform the job safety and efficiently. Combined with an employer's duty to accommodate, such an approach to lawful physical standards for employment conceives of worker and public safety and workplace diversity as emanating from a shared concern for human rights.
\end{abstract}

Key words: physical standards for employment; human rights; discrimination; duty to accommodate

Conflict of Interest Disclaimer: The author declares no conflict of interest. 


\section{Introduction}

The Supreme Court of Canada's 1999 Meiorin decision has become a well-known landmark in Canadian human rights law, labour and employment law, disability law, and discrimination and equality jurisprudence more generally (British Columbia (Public Service Employee Relations Commission v British Columbia Government and Service Employees' Union (B.C.G.S.E.U.) (Meiorin Grievance) [1999] 3 SCR 3 [Meiorin 1999]). ${ }^{1}$ Canadian courts and arbitrators have cited the case well over 500 times, and, with only minor exception, its clarification of the approach to adjudicating discrimination claims, its emphasis on substantive equality, and its articulation of the employer's duty to accommodate under human rights law has been widely praised and followed (Sheppard 2001). ${ }^{2}$ In its journey to iconic status as a modern classic of Canadian law, however, Meiorin's factual context as a case of physical standards for employment has faded from view, at least for many lawyers. By contrast, the case occupies a central place among the researchers and experts engaged in the study, science, design, and implementation of physical standards of employment (Gillis and Darby 2001; Gledhill and Bonneau 2001). Within both legal and scientific communities, Meiorin is too often treated as a rigid set of rules divorced from its factual origins. A better understanding of Meiorin's facts, its

\footnotetext{
*Associate Professor, University of Alberta, Faculty of Law. I thank Michael Ginevsky, Lauren Chalaturnyk, and Siobhan Powlowski for research assistance. I also thank Stewart Petersen for several illuminating conversations, and for the insightful feedback of several anonymous reviewers.

${ }^{1}$ For context see Fudge, J. and Lessard, H. 2010. Challenging Norms and Creating Precedents: The Tale of a Woman Firefighter in the Forests of British Columbia. In Work on Trial: Canadian Labour Law Struggles. Edited by J. Fudge and E. Tucker. The Osgoode Society for Canadian Legal History, Toronto. pp. 315-.

${ }^{2}$ For a more critical perspective see Gall, P.A. and Chapman, S. Legislation by Litigation: Individualized Accommodation in the Workplace. (2012) 59 SCLR (2d) 381; Gillis, A.D. and Darby, B. 2001. To serve and protect, post Meiorin. In Proceedings of the Consensus Forum on Establishing Bona Fide Requirements for Physically Demanding Occupations. Edited by N. Gledhill, J. Bonneau, and A. Salmon. Toronto. pp. 85-.
} 
foundational principles, and its conceptual compatibility with international approaches, sets the stage for a more productive and widely applicable articulation of the best way to navigate the interaction of physical standards for employment and human rights concerns not only in Canada but across the common law world.

The Meiorin case began, not in the wood-panelled courtroom of the Supreme Court of Canada, or in Tawney Meiorin's grievance arbitration, or even in the running test that Ms. Meiorin failed by 49.4 seconds. The case began in a tragedy in the often-dangerous working conditions of British Columbia’s forests. In the summer of 1991, Ernest Gordon Kingston, a father of three young children, was part of a work crew employed by Weldwood of Canada logging a remote rugged section of British Columbia's sunshine coast. An experienced logger recently returned to work following a back injury, Kingston's main responsibilities included removing branches and bucking felled trees with a chain saw. On the morning of 1 August, on what was scheduled to be the crew's penultimate day at the site, cable friction or an engine malfunction in the logging machinery sparked a fire on the wood-strewn forest floor. The work crew swung into action battling the blaze, as required by British Columbia's Forest Act. After a few hours, the crew pulled out briefly while British Columbia Forest Service water bombers doused the flames. In the early afternoon, the crew returned to deal with the remaining hot spots from the ground. At that point, under the direction of the government Forest Officer and Weldwood managers, six workers, including Kingston, were sent down a steep embankment to spread water on an area of previously felled lumber. Kingston, a large 250-pound man, ventured furthest down the hill - a dangerous place to be. The wood debris along the slope, cut the previous year, was dry and highly combustible. Suddenly "the wind changed and the fire ... more or less exploded," one of the crew recalled. Surrounded by wind-fed flames the workers 
scrambled up the 75-meter cliff and towards the logging road. "When I saw the fire move I hollered at everyone to get out," the crew's manager recalled. "Between the roaring of the fire, the smoke and the heat, (Kingston) was overcome." When he died, Kingston was less than five meters from the safety of the road (Buttle 1991; Devlin 1991; Fraser 1991; Jackson 1991; The Sunshine Coast News 5 August 1991, p.1).

The ensuing Coroner's Inquiry Report, issued by D.A. Devlin, 29 November 1991, offered a series of recommendations to the British Columbia government and forest industry. Crucially, the Report noted that there had been confusion in the chain of command during the fighting of the fire and that Kingston "had received no formal training to fight fires." In addition to stressing the need for forestry companies to better train and prepare its employees to suppress fires, the Report recommended that "only workers who are physically fit and familiar with working in heavy brush conditions should be assigned front-line firefighting tasks" (Devlin 1991). The Coroner's recommendations led directly to the physical standards for employment that Tawney Meiorin failed.

Kingston's death is a powerful reminder of the inherent dangers of many workplaces. In Canada, as a matter of occupational health and safety legislation, criminal law, and common law, employers must provide, insofar as possible, a safe and healthy work environment for their employees. ${ }^{3}$ It is equally clear that in some occupations, including emergency responders and

${ }^{3}$ See, for e.g., Alberta's Occupational Health and Safety Act, RSA 2000 c O-2, s 2(1) which obligates employers to "ensure, as far as it is reasonably practicable ... to do so ... the health and safety of" its workers. In addition, the Criminal Code, RSC 1985, c C-46, s. 217.1 provides: "Everyone who undertakes, or has the authority, to direct how another person does work ... is under a legal duty to take reasonable steps to prevent bodily harm to that person, or any other person, arising from that work". As Justice MacDonnell wrote in a recent sentencing decision under s. 217.1, $R v$ Kazenelson, 2016 ONSC 25 at para 45: "persons in positions of authority in potentially dangerous workplaces have a serious obligation to take all reasonable steps to ensure 
heavy industry, public safety and property is also at stake in effective job performance. In appropriate settings, physical standards for employment are among the important ways that employers can maintain and enhance workplace safety for workers and the public alike by ensuring that individuals in potentially dangerous working conditions are able to safely manage the physical demands of the job. But the accident that led to Kingston's death and the testing that resulted from it also reveals the ways in which physical standards for employment can be inappropriately transplanted from one context to another, or implemented with discriminatory impact. If the lesson of Kingston's death is about the need to protect workers and the public from harm, it is also about the need to tailor those protections in light of human rights values, and to insist that the imposed standard is directly and closely connected to the specific workplace at issue. This article is about approaching the legality of physical standards for employment with these lessons in mind. I argue that, if designed and implemented appropriately, physical standards for employment promote rather than inhibit workplace achievement of human rights objectives. From this perspective, physical standards for employment, when attentive to human rights and diversity concerns, play an important role in the creation of safe, just, and equitable workplaces.

\section{Part I: Discrimination at Work}

Physical standards for employment consist of employer-mandated requirements for employees to hold or continue employment. Such requirements typically take the form of physical tests that replicate, insofar as possible, the physical demands of the job. As Bruno Zumbo helpfully explains, employers, often with assistance from specialists, translate a

that those who arrive for work in the morning will make it safety back to their homes and families at the end of the day." 
"conceptual version of the desired level of competence, i.e. the performance standard" into a "cut-score on the test" as a delineation of acceptable and unacceptable performance (Zumbo 2016). The employer's use of such standards and tests in making important employment decisions - who to hire, fire, or retain - directly engages two fundamental legal concepts: freedom of contract and workplace human rights.

In its purest form, the common law doctrine of freedom of contract recognizes the right of individuals entering contracts, including employment contracts, to set the terms of that contract free from legislative restraint or judicial interference (Atiyah 1979). As the United States Supreme Court famously held, “[i]n making contracts of employment, generally speaking, the parties have equal right to obtain from each other the best terms they can by private bargaining" (Morehead v New York ex rel. Tipaldo, 298 US 587 (1936)). In Canada, like most other common law jurisdictions, freedom of contract remains among "the fundamental commitments of the common law of contract" (Bhasin v Hrynew, [2014] 3 SCR 494, para 70). Accordingly, among the most important contractual freedoms recognized by the common law is the decision of whether to enter into a contract first place, or to continue a contractual relationship. Physical standards for employment, as a basis to make decisions of whom to hire, discipline or terminate, are expressions of contractual freedom, including an employer's management rights to organize the workplace, and set its rules, policies, and working conditions.

But unfettered freedom to contract also entails a freedom to discriminate. Discrimination in the workplace was not historically a topic of legislative or judicial concern. In Canada, as elsewhere, for much of the twentieth century, explicit workplace discrimination against Indigenous peoples, women, racial and visible minorities, and disabled persons closed many 
fields of employment and limited workplace opportunities. ${ }^{4}$ Despite the persistence of subtle and systemic forms of workplace discrimination, the human rights revolution in the latter half of the twentieth century had a profound impact on employment law across the common law world.

With the framing of the Second World War as a fight for individual rights and freedom against Nazi racism and oppression, the passage of the Universal Declaration of Human Rights in 1948, and social, legal, and labour movement activism against on-going civil liberties abuses, a new attention to domestic human rights protection swept across Canadian legal and political culture, just as similar movements took shape across the western world (Adams 2009; Clément 2008).

The first legislative steps to protect human rights in Canada were tentative. In 1944, Ontario prohibited the publication or display of "any notice, sign, symbol, emblem or other representation indicating discrimination or an intention to discriminate against any person ... because of the race or creed of such person" (Racial Discrimination Act, SO 1944, c 51, s 1). Saskatchewan followed with the first comprehensive provincial bill of rights, providing that “[e]very person ... shall enjoy the right to obtain and retain employment without discrimination ... because of the race, creed, religion, colour or ethnic or national origin of such person" (Saskatchewan Bill of Rights, SS 1947, c 35, s 8). Although symbolically important, the absence

${ }^{4}$ In the period before the arrival of human rights legislation, the law generally responded to workplace discrimination in two ways. In some instances, governments wrote sexism, racism, and prejudice directly into the formal law itself, by denying government contracts to certain visible minorities. Far more prevalent, however, were the informal lines, barriers, and quotas among private and public employers that prevented full participation in the workforce: applications ignored, promotions denied, terminations expedited. This form of legalized discrimination fit squarely within the traditional common law conceptions of employment and the freedom to contract, as the unfettered rights of private parties to act as they saw fit. The private law in Canada, as the majority of the Supreme Court of Canada held in Christie v York [1940], SCR 139, p. 146, its famous decision upholding the right to deny service on the basis of race, "is that of complete freedom of commerce .... [a]ny merchant is free to deal as he may choose with any individual member of the public. It is not a question of motives or reasons..." That same logic applied to matters of employment. See Adams 2012; Backhouse 1999; Patrias 2007; Frager \& Patrias 2005. 
of practical enforcement mechanisms meant that neither law managed to curb workplace discrimination. Seeking greater impact, Ontario enacted the Fair Employment Practices Act in $1951,{ }^{5}$ adapting a legislative model from the State of New York, prohibiting discrimination in employment, and establishing a commission to monitor and enforce the legislation (Tarnopolsky 1982, pp. 27-28). The model quickly spread as other Canadian provinces adopted fair employment legislation. In 1962, Ontario consolidated its various human rights legislation into one human rights statute to be fully administered by a human rights commission. Other Canadian provinces followed with human rights codes and commissions of their own (Howe \& Johnson 2000).

It is worth noting two features of this first wave of human rights legislation. First, the legislative concern was employment discrimination based on race, religion, ethnic, and national origin. ${ }^{7}$ For the most part, discrimination on the basis of sex or gender was not prohibited.

\footnotetext{
5 The Act's preamble declared: "it is contrary to public policy in Ontario to discriminate against men and women in respect of their employment because of race, creed, colour, nationality or place of origin; ... it is desirable to enact a measure designed to promote observance of this principle; and ... to do so is in accord with the Universal Declaration of Human Rights as proclaimed by the United Nations".

${ }^{6}$ In Canada, human rights commissions, like the regulation of employment itself, generally fall within provincial jurisdiction. The exception is employment at a handful of federally-regulated industries, such as aeronautics, banking, and telecommunications, which fall under federal constitutional authority. Accordingly, employment and labour relations are overwhelmingly regulated at the provincial level. Employment standards legislation sets a number of minimum contractual conditions (pay, maximum hours of work, amount of reasonable notice to terminate) that the parties to a contract cannot, either implicitly or explicitly, avoid. Labour relations legislation governs unionization and the collective bargaining of workplaces. Occupational health and safety legislation obligates employers to provide and maintain a healthy and safe work environment. Human rights law prevents employers from refusing to hire or to continue to employ individuals on the basis of a set of prohibited grounds of discrimination. Employment at federally-regulated industries is governed by the Canada Labour Code, RSC $1985 \mathrm{c}$ L-2 and the Canadian Human Rights Act, RSC 1985, c H-6.

${ }^{7}$ Although the federal Canadian Bill of Rights, SC 1960, c 44 protected against discrimination within federal laws on the grounds of "sex," the legislation had little impact on employment and labour law. On the contrary, the Canadian Bill of Rights became infamous for a series of judicial
} 
Neither did early human rights codes protect individuals from discrimination based on physical or mental disability (Pothier 2010-2011, p. 19). Secondly, the prohibition against workplace discrimination - albeit on a relatively narrow list of grounds - was absolute. Early human rights codes contained no exception for what would later become known as bona fide occupational requirements. As sex discrimination continued in the workplace and as the women's movement increasingly demanded the extension of human rights protection to women, sex was added as a prohibited ground of discrimination, first in British Columbia in 1969, and to the other provincial human rights codes in the years which followed (Clément 2014). Throughout, the American legislative experience continued to serve as a model. Title VII of The Civil Rights Act of 1964 broke new ground by prohibiting employment discrimination against individuals on the basis of "race, color, religion, sex, or national origin" (§ 7, 42 USC $§ 2000$ e et seq (1964)). Ironically, the last-minute insertion of "sex" among the prohibited grounds was likely a ploy by opponents of the legislation to defeat it by extending its protections to women (Miller Jr, 1966-67, p. 879). Although the effort to derail the legislation failed, the addition to the grounds of discrimination prompted Congress to include the defence of "a bona fide occupational qualification reasonably necessary to the normal operation of that particular business or enterprise" as a way of softening the legislation's impact. ${ }^{8}$ Early commentators correctly identified that the phrase offered "the key to the enforcement of the act" (Miller Jr, 1966-67, p. 879). Although, as Miller pointed out, "[t]he language is at best ambiguous, and admits of a wide range of possible interpretations" (Miller Jr, 1966-67, p. 879).

interpretations by the Supreme Court of Canada that seemed to entrench existing inequality on the basis of sex (AG Canada v Lavell, [1974] SCR 1349, and Bliss v AG Canada, [1979] 1 SCR $183)$.

${ }^{8}$ Notably the defence only applied to claims of discrimination on the basis of "religion, sex, or national origin". Race was excluded. 
The American legislative concept of a bona fide occupational qualification as a full defence to a claim in employment discrimination migrated first to Alberta's Human Rights Act in 1966 (although without the addition of sex as a prohibited ground of discrimination). In 1969, when British Columbia added sex to its list of prohibited grounds it included the qualification that "discrimination because of sex, where based on a bona fide occupational qualification, does not constitute" a breach of the Act (Human Rights Act, SBC 1969, c 10, s 5). In the decade that followed, every Canadian human rights statute prohibited sex discrimination alongside some variation of the concept of a bona fide occupational qualification (Clément 2014, p. 74). That remains, more or less, the governing statutory landscape in Canada today, although several jurisdictions have moved to use the preferable language of a "bona fide occupational requirement" as opposed to "bona fide occupation qualification". Similarly, "physical disability" first appeared as a protected ground in New Brunswick's human rights legislation in 1976, before spreading across the country in the ensuing decade (Pothier 2010-2011).

If freedom of contract makes possible the setting of physical standards of employment as elements of the employment contract, human rights norms and the legislation which enforce them provides the legal limits of those standards. Prospective employees who fail to pass a physical standard for employment test and fail to obtain a job, or incumbent employees disciplined or terminated for failure to pass an employer-imposed test, will have a human rights claim in the event that the test discriminated against them on the basis of a protected ground of discrimination, such as sex/gender, physical disability, or age, and failed to qualify as a bona fide occupational requirement. 
There are minor variations in format and wording among Canada's provincial human rights codes in relation to employment discrimination. The Alberta Human Rights Act, RSA 2000, c A-25.5, for example, provides as follows:

7(1) No employer shall

(a) refuse to employ or refuse to continue to employ any person, or

(b) discriminate against any person with regard to employment or any term or condition of employment,

because of the race, religious beliefs, colour, gender, physical disability, mental disability, age, ancestry, place of origin, marital status, source of income, family status or sexual orientation of that person or of any other person. $\cdots$

(3) Subsection (1) does not apply with respect to a refusal, limitation, specification or preference based on a bona fide occupational requirement.

Some other statutes define discrimination, ${ }^{9}$ while others specify that a bona fide occupational requirement requires individual accommodation to the point of undue hardship. ${ }^{10}$ In reality, none

\footnotetext{
${ }^{9}$ The Canadian Human Rights Act, RSC 1985, c H-6, s 10, provides that discrimination "deprives or tends to deprive an individual or class of individuals of any employment opportunities on a prohibited ground of discrimination." The Nova Scotia Human Rights Act, RSNS 1989, c 214, s 4, defines discrimination as occurring when "the person makes a distinction, whether intentional or not, based on a characteristic, or perceived characteristic, [based on a prohibited ground] that has the effect of imposing burdens, obligations or disadvantages on an individual or a class of individuals not imposed upon others or which withholds or limits access to opportunities, benefits and advantages available to other individuals or classes of individuals in society." See also, Manitoba's Human Rights Act, CCSM c H175, s 9.
} 
of these differences, beyond a few small variations in the prohibited grounds themselves, have tended to matter in practice. ${ }^{11}$ Courts, human rights commissions, and labour arbitrators alike have confirmed in all Canadian jurisdictions that, regardless of small differences in wording, discrimination in employment, including any legal challenge involving physical standards for employment, is to be adjudicated on the basis of the conceptual framework established by the Supreme Court of Canada in the Meiorin decision.

To the extent physical employment standards and the tests that arise from them pass human rights challenge (either directly under human rights legislation or indirectly as incorporated into workplace collective agreements), they are fully lawful in the employment context. To the extent that they discriminate and fail to qualify as bona fide occupational requirements, they are illegal and may give rise to claims in damages. Regardless, physical standards for employment expose employers to human rights litigation and workplace grievances. Despite varying statutory contexts, physical standards for employment raise similar legal issues across the common law world. Yet while the scientific research community behind the creation and study of physical standards for employment has long been informed by international conversations and collaboration, the human rights and legal dimensions have remained tenaciously limited by national boundaries. A look behind the distinctive legal

${ }^{10}$ Ontario's Human Rights Code, RSO 1990, c H 19, s 11, for e.g., provides: "The Tribunal or a court shall not find that a requirement, qualification or factor is reasonable and bona fide in the circumstances unless it is satisfied that the needs of the group of which the person is a member cannot be accommodated without undue hardship on the person responsible for accommodating those needs, considering the cost, outside sources of funding, if any, and health and safety requirements, if any."

${ }^{11}$ As Chief Justice Lamer held in University of British Columbia v Berg, [1993] 2 SCR 353 at 373: "If human rights legislation is to be interpreted in a purposive manner, differences in wording between provinces should not obscure the essentially similar purposes of such provisions, unless the wording clearly evinces a difference purpose on behalf of a particular provincial legislature." 
language of common law countries, however, reveals a world of overlapping issues and common solutions.

\section{Part II: Comparative Context: Unites States, United Kingdom, and Australia}

Not surprisingly, workplace discrimination and its adjudication under human rights norms raise similar legal issues across the western world. Despite structurally and conceptually similar legal systems among common law countries, most jurisdictions have developed their particular jurisprudence concerning the legality of physical standards for employment in isolation from one another. We have already seen, however, that cross-border influences between the United States and Canada played an early role in shaping Canadian human rights legislation, an international rights conversation that touched many other national legal systems as well. There are important lessons to be generated from a comparative analysis of the case law of different national jurisdictions, and a common best practices approach to physical standards of employment that can be utilized regardless of national context.

The United States Supreme Court has not yet decided a case dealing with physical standards for employment under the Civil Rights Act, although its famous decision in Griggs $v$ Duke Power Co., dealing with employment discrimination and race, widely influenced the case law trajectories in a number of jurisdictions, and establishes an important starting point for analysis (401 US 424 (1971) [Griggs 1971]). In that case, the Court struck down an employer's policy of requiring a high school diploma and passage of a written standardized test as a prerequisite to employment at a public utility company as racial discrimination under the Civil Rights Act. The decision is important for holding that the intention to discriminate is unnecessary to a finding of discrimination, and that facially neutral standards might nonetheless operate to discriminate in what became known in the United States as "adverse impact" or "disparate 
impact" discrimination (Lindemann \& Grossman 2007). ${ }^{12}$ Both forms of discrimination were subsequently prohibited in both Title VII of the Civil Rights Act and under the Americans with Disabilities Act of 1990 (Pub L 101-336, 104 Stat 328 (1990)). ${ }^{13}$ In Griggs, the Court held that "practices, procedures, or tests neutral on their face, and even neutral in terms of intent, cannot be maintained if they operate to 'freeze' the status quo of prior discriminatory employment practices" (Griggs 1971, p. 429). "What is required," the Court held, "is the removal of artificial, arbitrary, and unnecessary barriers to employment when the barriers operate invidiously to discriminate" (Griggs 1971, pp. 429, 431). In a poetic turn, the Court held that “tests or criteria for employment or promotion may not provide equality of opportunity merely in the sense of the fabled offer of milk to the stork and the fox....The Act proscribes not only overt discrimination but also practices that are fair in form, but discriminatory in operation. The touchstone is business necessity" (Griggs 1971, pp. 429, 431). ${ }^{15}$ Since neither of the tests imposed in Griggs "is shown to bear a demonstrable relationship to successful performance of the jobs for which it was used," they could not pass legal muster (Griggs 1971, pp. 429, 431). Recall, however, that cases involving discrimination on the basis of race, as opposed to religion, sex, or national origin, under the Civil Rights Act are not subject to the defence of bona fide occupational qualification. Although Griggs helped to elucidate the American approach to

${ }^{12}$ In Canada, the same concept is referred to as "adverse effects" discrimination. See Ontario (Human Rights Commission) v Simpson-Sears, [1985] 2 SCR 536; Eldridge v British Columbia (Attorney General), [1997] 3 SCR 624.

${ }^{13}$ Raytheon Co v Hernandez, 540 US 44 at 53: "Both disparate-treatment and disparate-impact claims are cognizable under the ADA."

${ }^{14}$ The Civil Rights Act of 1991, 42 USC $§ 2000 \mathrm{e}-2(\mathrm{k})$ (2000), codified the concept of adverse impact discrimination from Griggs.

${ }^{15}$ In the ancient fable, the fox offers the stork milk from a bowl that the stork's beak will not allow him to use, while the stork offers the fox milk from a long-necked bottle that the fox cannot drink from. 
workplace testing and adverse impacts discrimination, it left the issue of the meaning of bona fide occupational qualification unresolved.

In subsequent cases, the United States Supreme Court confirmed an approach to employment discrimination that interprets the bona fide occupational qualification defence "narrowly," to apply only to "objective, verifiable requirements" that "concern job-related skills and aptitudes" (United Auto Workers v Johnson Controls Inc, (1991), 499 US 187, p. 201). In a case involving an employment requirement that prison guards in Alabama weigh a minimum of 120 pounds and stand taller than 5 feet, 2 inches, the Court held that the requirements had an adverse impact on prospective female applicants and could not be saved as job related since the employer produced no evidence of the necessary relationship between height, weight, and physical job demands. The Court explicitly left open, however, the possibility that a more focused test on strength if "fairly administered" could qualify as a bona fide occupational qualification "because it would be one that "measure(s) the person for the job and not the person in the abstract" (Dothard v Rawlison, (1975) 433 US 321, p. 332). Indeed, the Civil Rights Act itself explicitly allows "any professionally developed ability test provided that such test, its administration or action upon the results is not designed, intended or used to discriminate because of race, color, religion, sex or national origin," while also specifically prohibiting employers "to adjust the scores of, use different cut-off scores for, or otherwise alter the results of, employment related tests on the basis of race, color, religion, sex, or national origin."

Today, the structure of the Civil Rights Act requires plaintiffs to "establish a prima facie case of disparate impact by demonstrating that application of a facially neutral standard has resulted in a significantly discriminatory hiring pattern." At that point, the onus shifts to the defendant to demonstrate that "the employment practice is "job related for the position in 
question and consistent with business necessity". The plaintiff's case may still succeed, however, if she can prove that "an alternative employment practice has a less disparate impact and would also serve the employer's legitimate business interest" (Lanning v Southeastern Pennsylvania Transportation Authority (SEPTA), (1999) 181 F 3d 478 (3d Cir) [Lanning 1999]). ${ }^{16}$

Controversies and disagreements have nonetheless flowed from both the particular meaning of the relevant operative phrases - "business necessity" and "job related" - and what degree of proof and evidence are required to demonstrate that a particular test constitutes adverse impact discrimination in the first place. Lower courts have grappled with such questions in many cases dealing with various kinds of cognitive, mechanical, and physical standards testing, all of which have historically been widespread in the public and private sector in the United States. Judicial results have been inconsistent in the absence of a binding decision on physical standards for employment from the Supreme Court, but trends are nonetheless discernable.

In the United States, challenges to pre- and post-employment testing occur under either the Civil Rights Act, on the basis of sex, or under the Americans with Disabilities Act of 1990, on the basis of disability. In a manner very similar to the structure followed in Canada, under the Americans with Disabilities Act of 1990, a plaintiff challenging such testing as discriminatory bears the burden of proving adverse effects discrimination, while the defendant employer carries the onus of justifying why it could not make "reasonable accommodations" to the point of "undue hardship." In the United States, employers seeking to implement pre- and post-

\footnotetext{
${ }^{16}$ See generally, Barbara T Lindemann \& Paul Grossman, Employment Discrimination Law, $4{ }^{\text {th }}$ ed, vol 1 (Washington, DC: BNA Books, 2007) at 119, 141. As the authors explain, "[C]ourts have continued to hold that a plaintiff generally cannot establish a prima facie case under an adverse impact theory by showing only that the cumulative impact of the employer's selection procedures results in an adverse impact on members of a protected class. Rather, a plaintiff generally must identity a particular part of the selection process that causes the adverse impact." See also Wards Cove Packing Co. v Atonio, 490 US 642.
} 
employment testing of its applicants and employees, typically take guidance from the federal Uniform Guidelines on Employee Selection Procedures in order to immunize their testing from judicial review. The Guidelines define discrimination as adverse impact on the basis of sex, race, or ethnic group using the widely embraced $80 \%$ rule, i.e. if the pass rate of the protected group is less than $80 \%$ of the pass rate of the majority group of participants. Adverse impact, however, may still be lawful if the physical test nonetheless is sufficiently job-related. The judiciallysanctioned Guidelines authorize three forms of testing which have consequences for physical standards for employment: construct validation, criterion validation, and content validation (Rutherglen 2010). Construct validation tests abstract skills with a relationship to job performance, (i.e. strength, speed, and agility testing as an indication, for example, of the ability to adequately carry a hose up a ladder). Content validation tests specific aspects/skills directly related to the performance of the job, (i.e. the ability to carry a hose up a ladder). Criterion validation tests knowledge or skills against an established set of criteria which measure adequate or proficient performance, (i.e. the ability to carry a hose up a ladder in a prescribed safe, efficient, and timely manner). American courts have tended to prefer content and, especially criterion validation, as opposed to construct validation in assessing the legality of job-related testing because of the obviously more precise connection between the testing mechanism and the actual demands of the job (Berkman v City of New York, (1982) 536 F Supp 177).

Even if the test itself is well aligned with job performance, courts will further inquire into the relationship between the acceptable cut score and the actual demands of the job. Justice Posner, for example, soundly rejected employing physical standards testing for firefighters that arbitrarily set a cut-off score one standard deviation from the mean performance times of (mostly) male firefighters. The result, the Court held, was a test that disproportionately 
negatively impacted women and for which the employer could offer no justification based on the actual requirements of the job (Evans v City of Evanston, (1989) 881 F 2d 382). Similarly rejecting the bare justification that more physical capacity is better than less in transit police officers, the Third Circuit, rejected a running (construct validation) test (1.5 mile run within 12 minutes) because the employer failed to demonstrate how the cut-off score related to the “minimum qualifications necessary to perform successfully the job in question” (Lanning 1999). On remand, however, the District Court emphasized the public safety aspect of the job and found that the employer adduced sufficient evidence to prove that the running test served to adequately measure crime-fighting ability to qualify as a "business necessity" (Lanning v Southeastern Pa Transp Auth, (2002) 308 F 3d 289, (3d Circ). Even so, the wiser course for employers remains the use of content and criterion validation with evidence of a strong correspondence between the test, the cut score and necessary minimum workplace safety objectives. It is also the case that the mere demonstration of an adverse effect on the basis of sex or disability will not suffice to strike down physical employment testing. In the United States, it is the nature and use of the testing and its relationship to demonstrable legitimate objectives that determines its legality.

Likewise in the United Kingdom and Australia, protection against employment discrimination emerges from human rights legislation prohibiting workplace discrimination. In both jurisdictions, physical standards for employment have not figured prominently in discrimination case law to date, although there is no reason to think that physical standards for employment might not be the subject of future legal challenge. ${ }^{17}$ Britain's Equality Act 2010

\footnotetext{
${ }^{17}$ One of the few UK cases dealing with a physical standards for employment, found that a running test for police officers that set different cutoff times for men and women, discriminated against the male applicant since his time would have been sufficient as a female applicant: Allcock v Chief Constable, Hampshire Constabulary, ET Case No. 3101524/97 cited in Discrimination at Work 2012, p. 781).
} 
consolidated and harmonized a number of previous disparate enactments prohibiting discrimination, including in employment. Developed under the influence of European Union discrimination law, Britain's legislation bears strong similarities to Canadian and American human rights legislation and enforcement. The statute prohibits direct and indirect discrimination in the workplace upon an expansive list of grounds, including age, disability, sex, race, and religion, with an exception for "occupational requirements". The statute does not define the meaning of occupational requirements, and there remains some confusion among commentators about whether occupational requirements reflect factors "crucial to the post" or, the lesser standard of simply "a link between the requirement and the job" (Discrimination at Work 2012, p. 759). In some instances, the legislation also holds employers to a duty "to make reasonable adjustments" in the context of discrimination based on disability, arguably akin to the Canadian duty to accommodate to the point of undue hardship. Although few cases have arisen for judicial determination, it seems likely that British courts will uphold physical employment tests as occupational requirements where employers can clearly demonstrate the connection between the test, cut score and job performance. In the case of disabled individuals, employers will additionally have to demonstrate why it would not be possible to adjust workplace duties in order to accommodate the individual.

A similar series of state- and federally-enacted statutes govern workplace discrimination in Australia. ${ }^{18}$ There have been few if any physical standards for employment cases brought under Australian discrimination legislation, perhaps because of the broader legislative exception to discrimination claims if a disability makes an individual "unable to carry out the inherent

${ }^{18}$ At the federal level see the Racial Discrimination Act 1975; Sex Discrimination Act 1984; the Disability Discrimination Act 1992; and the Age Discrimination Act 2004. See generally Chris Ronalds \& Elizabeth Raper, Discrimination Law and Practice, $4^{\text {th }}$ ed (Sydney: Federation Press, 2012). 
requirements of the particular work, even if the relevant employer ... made reasonable adjustments for the aggrieved person" (The Discrimination Act 1992, Act No 135 of 1992, s 21A(1)). In a series of cases dealing with potentially discriminatory adverse impact terminations, the Australian High Court interpreted "inherent requirements of the particular work" to encompass the "essential requirements of the employment," including the broader regulatory and industrial context in which that work necessarily takes place (Qantas Airways v Christie, [1998] HCA 18, paras 32-35, Xv Commonwealth of Australia, [1999] HCA 63, paras 31, 102 [Commonwealth of Australia 1999]). “[C]arrying out the employment without endangering the safety of other employees," Justice McHugh added, "is an inherent requirement of any employment" (Commonwealth of Australia 1999, para 32). Employers, accordingly, will be able to justify adverse impact physical standards of employment testing under Australian human rights law where they can demonstrate that the test directly relates "to the essential elements, hazards and inherent requirements of the job in question," and that "reasonable adjustments" to the workplace to accommodate the employee are not possible (Guthrie and Westaway, p. 809).

Despite obvious differences in legislative wording and comprehensiveness, Canada, the United States, the United Kingdom and Australia each employ a reasonably similar model of dealing with workplace discrimination, at least on paper. All jurisdictions prohibit direct and indirect forms of employment discrimination upon similar grounds. Similarly, each jurisdiction allows for limited exceptions on the basis of particular job requirements, and, in some cases, an additional duty that an employer must accommodate individual applicants and employees to a reasonable degree. Canada and the United States have the most developed jurisprudence in relation to physical standards for employment and perhaps greater receptivity to equality rights challenges of workplace rules, but it is safe to say that judicial outcomes in the United Kingdom 
and Australia concerning physical standards for employment if and when they originate will roughly track outcomes in North America, although the different wording among the applicable statutes and differences in legal cultures may account for variations at the margins.

What a survey of common law countries does make clear, is that although there has been considerable overlap and mutual influence among the key legal concepts and legislative language in play, the Canadian jurisprudence on physical standards of employment is arguably the best developed and consistent, in large measure because it is the only jurisdiction where the highest appellate court has directly dealt with a case involving physical standards for employment. For this reason, Meiorin may prove to be an important decision not only in Canadian human rights law, but potentially in international contexts as well. Regardless of its actual international impact, the legislative and judicial approach in Canada to physical standards for employment bears scrutiny and emulation for its effective balancing of human rights and diversity concerns, workplace safety, and contractual freedoms.

\section{Part III: Building Conceptions of Equality into Workplace Standards}

Any discussion of physical standards for employment in Canada will naturally focus on Meiorin. Tawney Meiorin began work as a contract firefighter in British Columbia in 1989. In the spring of 1992, the government employer hired her as a member of an Initial Attack Crew - a small team designed to fight and suppress early-stage forest fires. She worked the following summer under a similar arrangement. In both years, Meiorin's offer of employment stipulated that she was to pass a physical employment test; in neither year did any testing actually occur. She appears to have performed her job reasonably well. As the 1994 season approached, the government employer insisted that Meiorin pass (and re-pass throughout the term of 
employment) a physical test - the one created in response to Ernest Kingston's death and the Coroner's Inquiry recommendations that followed. As Justice McLachlin (as she then was) explained: "The Tests required that the forest firefighters weigh less than 200 lbs. (with their equipment) and complete a shuttle run, an upright rowing exercise, and a pump carrying/hose dragging exercise within stipulated times" (Meiorin 1999, para 6). Because of a previous knee injury, the employer excused Meiorin from the shuttle run and required instead that she complete a two-and-a-half kilometer run in less than eleven minutes. Meiorin failed the test three times, on the last occasion by 49.4 seconds. The government employer terminated Meiorin from her employment as a result.

Meiorin challenged her termination under the terms of her collective agreement (which referentially incorporated British Columbia's human rights legislation) on the basis that the physical standards for employment discriminated against her on the basis of sex. The government defended the termination on the grounds that "it is necessary periodically to test a person's physical fitness for the job ... to ensure that he or she is and remains fit to perform the job safely and effectively" (Respondent's Amended Factum at para 43). Although an earlier grievance arbitration had upheld the legality of physical testing job requirements for British Columbia forest fire fighters, Meiorin won her arbitration on the grounds that she had "performed her job as a forest firefighter satisfactorily in previous years without any concerns about her ability to perform her job safely and efficiently," and that the testing both discriminated against her and failed to accommodate her to the point of undue hardship (British Columbia (Public Service Employee Relations Commission v British Columbia Government and Service Employees’ Union (Meiorin Grievance), [1996] BCCA No. 441). After the British 
Columbia Court of Appeal overturned the arbitrator's decision, Meiorin's union appealed the case to the Supreme Court of Canada.

Meiorin was not the Supreme Court's first opportunity to interpret the meaning of statutory prohibitions on employment discrimination under human rights legislation. The Court had already developed, although without unanimity, the elements of bona fide occupational requirements to include subjective good faith, objective reasonable necessity, and individual accommodation to the point of undue hardship (Ontario (Human Rights Commission) v Borough of Etobicoke, [1982] 1 SCR 202; Central Dairy Pool v Alberta (Human Rights Commission, [1990] 2 SCR 489, p. 513-14). Until Meiorin, however, the Court had suggested that the applicable test may differ when dealing with direct discrimination (e.g. women need not apply) as opposed to adverse effects discrimination (e.g. employees must be six feet tall) (Ontario Human Rights Commission and O'Malley v Simspons-Sears, [1985] 2 SCR 536; Central Dairy Pool v Alberta (Human Rights Commission, [1990] 2 SCR 489). Meiorin's principal doctrinal contribution was in uniting a unanimous Supreme Court to clarify and standardize a single test for adjudicating all forms of employment discrimination under Canadian human rights law. Since Meiorin, the operative three-part test "for determining whether a prima facie discriminatory standard is a bona fide occupational requirement" requires an employer to establish on a balance of probabilities as follows:

1) that the employer adopted the standard for a purpose rationally connected to the performance of the job;

2) that the employer adopted the particular standard in an honest and good faith belief that it was necessary to the fulfilment of that legitimate work-related purpose; and 
3) that the standard is reasonably necessary to the accomplishment of that legitimate work-related purpose. To show that the standard is reasonably necessary, it must be demonstrated that it is impossible to accommodate individual employees sharing the characteristics of the claimant without imposing undue hardship upon the employer (Meiorin 1999, para 54).

In Meiorin, Justice McLachlin for a unanimous Supreme Court agreed with the original arbitrator in holding that British Columbia's physical standard for employment discriminated against Meiorin, and was not a bona fide occupational requirement when evaluated under step three of the three-part test.

Meiorin established the template for adjudicating any form of discrimination under human rights law in Canada. Most often the case is cited for its three-part test and, in particular, its discussion of the concept of individual accommodation and undue hardship under step three. Indeed, in the employment context there have been few if any cases decided on the basis of the first two-steps - i.e. that the employer's decision or imposed standard bears no rational connection to job performance or was imposed in bad faith. Virtually every case turns on an assessment of whether the decision or standard was "reasonably necessary" and whether the employer can "accommodate the claimant and others adversely affected by the standard without experiencing undue hardship" (Meiorin 1999, para 62). The assessment of undue hardship in step three continues to receive a great deal of academic and judicial attention (Gillis and Darby 2001; Lynk 2002), but for our purposes it is useful to focus on how this requirement interacts with physical standards for employment. 
It is important to note that two background considerations influenced the Court's approach to discrimination and bona fide occupational requirements in Meiorin. The first is longstanding attention to the inherent vulnerability of employees in employment relationships and, in particular, in moments of job loss. "Work," as Chief Justice Dickson famously held, "is one of the most fundamental aspects in a person's life, providing the individual with a means of financial support and, as importantly, a contributing role in society. A person's employment is an essential component of his or her sense of identity, self-worth and emotional well-being" (Reference re Public Service Employee Relations Act (Alta.), [1987] 1 SCR 313, p. 368). ${ }^{19}$ It matters that a physical standard for employment may determine whether an individual keeps or loses her job. Secondly, earlier in her reasons, Justice McLachlin noted that discrimination claims under human rights legislation should be harmonized with the judicial approach taken under the equality rights provisions of the Canadian Charter of Rights and Freedoms. From the outset of its equality jurisprudence, the Supreme Court has emphasized that the Charter's guarantee of equality rights is intended to promote and protect the notion of "substantive" as opposed to "formal" equality. As Justice McIntyre put it, "every difference in treatment between individuals under the law will not necessarily result in inequality and, as well, that identical treatment may frequently produce serious inequality" (Andrews v Law Society of British Columbia, [1989] 1 SCR 143, p. 164).

Unquestionably, the Court's constitutional conception of substantive equality, its concern for the equal worth and human dignity of all persons, its attendant commitment to reviewing facially neutral standards, and its attention to the serious consequences of job loss informs its

\footnotetext{
${ }^{19}$ On the inherent vulnerability of employees see Machtinger v HOJ Industries Ltd., [1992] 1 SCR 986 at para 31.
} 
approach to physical standards for employment in Meiorin. Accordingly, in Meiorin, Justice McLachlin emphasizes:

Employers designing workplace standards owe an obligation to be aware of both the differences between individuals, and differences that characterize groups of individuals. They must build conceptions of equality into workplace standards. By enacting human rights statues and providing that they are applicable to the workplace, the legislatures have determined that the standards governing the performance of work should be designed to reflect all members of society, in so far as this is reasonably possible (Meiorin 1999, para 68).

In theory, if not always in practice, that commitment means that Canadian courts and tribunals will remain sensitive to systemic workplace discrimination. It seems likely that public employers will also increasingly face pressure from the public and government to address systemic underrepresentation of women and minorities in the public workforce, such as municipal fire fighters, and to examine the ways that using physical testing or ranking candidates according to such physical testing may contribute to reinforcing dominant patterns of workplace exclusion.

Nevertheless, the Court in Meiorin devotes very little attention to spelling out precisely why and how the physical standards for employment at issue discriminate. Recall, the onus lay on Meiorin to first prove on a balance of probabilities that the testing discriminated against her on a prohibited ground, "sex". In Meiorin, the Court agreed with the original arbitrator that the "aerobic standard discriminates against her as a woman," without much explanation or analysis. "Because of their generally lower aerobic capacity," the Court held, "most women are adversely affected by the high aerobic standard" (Meiorin 1999, para 68). What is unclear from this 
wording is whether virtually every physical standard for employment that tests, to a significant extent, speed, strength, or endurance will therefore prima facie discriminate against women because of the inherent physiological differences between men and women (Roberts et. al 2016; Cox and Messing, p. 25). ${ }^{20}$ In Meiorin, the Court adopted the arbitrator's holding that that "the test does have a discriminatory effect on women because women are less able to do aerobic work than are men. That is because of different physiological characteristics when women are compared with men" (Meiorin 1996, para 172). As the Supreme Court of Canada recently held, "to demonstrate prima facie discrimination, complainants are required to show that they have a characteristic protected from discrimination under the Code; that they experienced an adverse impact with respect to the service; and that the protected characteristic was a factor in the adverse impact" (Moore v British Columbia [2012] 3 SCR 360, para 33). In other words, regardless of the presence or absence of women test subjects in devising the physical standard, test, and cut score, it remains the case that virtually any testing mechanism that relies substantially upon physical strength, speed, or endurance is likely to be found to prima facie discriminate against women, as well as other individuals based on the protected grounds of disability and, in some cases, age.

It is also irrelevant in determining whether a test prima facie discriminates on the basis of sex, whether some women are capable of passing the physical test, with or without training. By definition, the physiological differences between men and women will give some men a systemic advantage in most physical standards testing. The same general advantages will also usually hold

\footnotetext{
${ }^{20}$ As Cox and Messing explain, “although there is always overlap between women's and men's performance in terms of strength and aerobic capacity, because of biological differences, we can generally expect that most women will not perform as well as most men on current physical employment tests. Men and women differ in terms of size, shape, muscle mass and energy metabolism. Length of body segments, body weight, and lifting ability are distributed differently by sex but with considerable overlap" (Cox and Messing, p. 25).
} 
true for able-bodied individuals in physical tests, compared to individuals with physically disabilities. In all likelihood, of course, the individual challenging the workplace decision will have failed to pass the imposed test. There may be certain kinds of physical standards with attributes for success distributed evenly across the population, which will not systemically discriminate against a group protected under human rights legislation. However, many physical tests for employment, especially ones dependent on strength, speed, or endurance, will constitute prima facie discrimination on the basis of sex, and often physical disability and age as well, if statutorily protected groups experience a more than trivial disadvantage in passing the test when compared to the majority population of participants. Thus far, Canadian courts have avoided defining disadvantage in rigid statistical terms akin to the $80 \%$ rule often employed in the United States. Canadian courts have thus far tended to prefer qualitative over quantitative measures, although fact finders and arbitrators will continue to rely on expert assessment of whether inherent group physiological capacities played a measurable role in an individual's inability to meet a cut-off score. Courts will often be further emboldened to make a prima facie finding of adverse effects discrimination since it is just the beginning, and not the end, of the analysis. The real legal issue on which virtually all such cases will turn is whether the physical standards of employment can be saved as bona fide occupational requirements. It is at that point that the design of the standard, test, and cut score, and the incorporation of diverse test subjects in their creation, may help to insulate the physical standards of employment from human rights challenge.

Within Meiorin's three-part test an arbitrator, tribunal, or court will almost always focus on step three: whether the "standard is reasonably necessary" to accomplish a "legitimate workrelated purpose" and whether it is possible to accommodate the employee (and others like her or 
him) "without imposing undue hardship upon the employer". In Meiorin, the onus fell on the government employer to demonstrate "that this particular aerobic standard is reasonably necessary in order to identify those persons who are able to perform the tasks of a forest firefighter safely and efficiently" (Meiorin 1999, para 72). In essence, the third step involves two discrete inquiries: the first into the imposed standard itself: its origins, purposes, design theory, and relationship to actual employment requirements; and secondly into the possibility of accommodating the individual given the demands and characteristics of the particular workplace involved. On the first issue, the Court in Meiorin laid particular stress on two problematic aspects of the research design of the impugned running test. First, the Court pointed out that the researchers had developed the standard based on "average performance levels of the test subjects" as opposed to a focus on actual job performance-based needs. And secondly, that in devising those averages the researchers had failed to distinguish between "male and female test subjects" (Meiorin 1999, paras 9, 74).

In Meiorin, the Court held that the focus of the design and implementation of the test should have been on the "minimum aerobic capacity to perform the job safely and efficiently" (Meiorin 1999, para 76). In other words, to qualify as a bona fide occupational requirement, a physical employment standard must represent a minimum (as opposed to an average or even preferable) level of safe and efficient job performance. Employers must be prepared to demonstrate with evidence, preferably in the research design and validation of the test itself, why a particular physical standard for employment offers an important job-related minimum threshold below which the job cannot be safely and efficiently performed. Employers will have an easier time of doing so if they can demonstrate that the physical standards, tests, and cut-off scores were derived from methodologically sound observation and testing of a diverse cross- 
section of individuals capable of performing the job safely and efficiently. The closer the nexus between the resulting physical standard test and the actual skills required and performed on the job, the more likely a tribunal or arbitrator will uphold the standard as a bona fide occupational requirement.

If an employer is able to demonstrate that a physical standard for employment qualifies as "reasonably necessary," it will additionally need to prove that it is impossible to accommodate the rights claimant to the point of undue hardship. A properly designed and implemented testing mechanism will go a long way to satisfying this portion of the test as well. That is, it will be far easier for an employer to demonstrate why individual accommodation of an employee unable to meet a particular standard will pose an undue hardship where the employer has already demonstrated that the required standard is a necessary minimum threshold sufficiently related to performance of the job. Some portions of Meiorin appear to suggest that an employer should consider establishing different employment standards for different groups of employees as part of its duties to accommodate individual employees. If that is what the Court suggests, I think it is inconsistent with earlier portions of the judgement and, in any event, unadvisable. To begin with, the use of different standards or cut-off scores undermines the first focus of step three: whether the standards are reasonably necessary. Imposing different standards, in effect, concedes either a) that the higher standard is not actually reasonably necessary or b) that individuals who pass the lower standard are not fully competent to safely and efficiently perform the job in question.

A better interpretation of the duty to accommodate in relation to physical standards for employment is to demand that an employer consider whether all aspects of a physicallydemanding job are really necessary for the safe and efficient functioning of the job. For example, employers must consider whether feasible changes in job technique or equipment might reduce 
the physical demands and thereby alter the minimum physical standard required for the disadvantaged employee. Similarly, an employer should consider whether various physical demands of a job might be disaggregated (temporarily or permanently) such that certain physical demands are no longer required in cases where an individual can otherwise perform the job in a satisfactory manner. ${ }^{21}$ And, of course, accommodation will also require an employer to consider whether an incumbent employee can be granted additional and supportive training time in order to meet a necessary standard before imposing termination. In other words, human rights legislation demands that employers and workplaces consider alternatives. Meiorin makes clear, and rightly so, that the mere fact of past practice, in and of itself, will not suffice in justifying adverse impacts job requirements. Employers imposing physical standards of employment must, on a routine basis, rigorously examine whether work can be performed with reduced physical demands for employees, and whether existing physical standards continue to reflect the actual demands of the job. At the same time, courts have repeatedly stressed that the purpose of human rights legislation is not to fundamentally transform the job at issue or the workplace in general. By focusing on truly necessary minimum physical standards, and by considering alternatives that might alter those standards in a feasible manner without significant sacrifice to successful job performance and safety, human rights norms maintain the laudable purpose of physical standards testing to keep workers and the public safe, while promoting an objective of workplace inclusion and diversity.

${ }^{21}$ As Arbitrator Giguère explains in striking down the DND's physical employment standard test for firefighters in Barr v Treasury Board (Department of National Defence), [2006] PSLRB 85 at 174-176, employers should consider whether it is necessary to have every employee pass a single standard or whether different standards might apply to different classes of employees based on different job requirements. For example, the employer should consider whether it was possible for stronger or fitter firefighters to be exclusively responsible for tasks demanding greater physical capacity. 
What Meiorin also makes clear is that simply asserting that a standard relates to safety will not be sufficient to qualify a physical standard for employment as a bona fide occupational requirement. Rather, a court will look specifically to evidence that the employer has made an individualized decision in relation to the employee, and that the employer engaged in a process of consideration rather than an automatic assumption that an individual cannot be accommodated. In this regard, an employer must consider available reasonable alternatives which do not alter "working conditions in a fundamental way" (Hydro Québec v Syndicat des employé-e-s, [2008] 2 SCR 561, para 16). In essence, human rights law requires an employer to defend with reasons why this particular employment standard has been imposed, and why this particular employee and others like her cannot be accommodated, considering factors such as prohibitive expense, onerous inefficiency, and compromised safety. Often answering these two queries will turn on the same considerations: the legitimate and demonstrable safety and efficiency concerns of the employer.

Despite the hundreds of occasions on which Meiorin has been cited in Canadian courts, relatively few cases have involved physical standards for employment. This may be in large part because employers moderated a number of physical tests in the wake of the Meiorin decision. After Meiorin, for example, the forestry company, Weyerhaeuser, abandoned its minimum bench press test and agreed to change its fitness test for millworkers to correlate "directly with the job being advertised" (Bolan 2000). The handful of Canadian physical standards cases that have been litigated since Meiorin confirm that a physical test for employment must bear a strong connection to the actual work being performed. In Barr v Treasury Board (Department of National Defence, Arbitrator Giguère invalidated the Department of National Defence's physical circuit firefighting test for a failure to justify its preferred cut-off score since the employer could 
not adequately defend the connection between the cut-off score and the minimum requirements to perform the job safely and efficiently ([2006] PSLRB 85). In addition, an employer must demonstrate why it is not possible to accomplish work tasks in less discriminatory ways. For example, an arbitrator struck down an employer's requirement that part-time cleaning staff be capable of lifting 50 pounds from floor to shoulder since the employer had no answer as to why heavy boxes of cleaning supplies could not be divided into lower weights, or why particularly heavy boxes could not be lifted by more than one person (Canadian Union of Public Employees, Local 4400 v Toronto District School Board (Shaw Grievance), [2003] OLAA No. 514). Any hardship occasioned by accommodating such practices was certainly not undue. Similarly, the Toronto Police Service could not adequately explain the connection between job performance and its hearing test requirements (Zaromitidis v Toronto Police Service Board and HMQ in Right of Ontario (Minister of Community Safety and Correctional Services), 2014 HRTO 1296). It was not enough to simply assert that police work is dangerous, engages public safety, and that hearing is important on the job. Under Meiorin, the employer must demonstrate the specific ways in which safety would be compromised by the complainant's hearing impairment.

In cases where physical standards have been upheld, by contrast, decision makers have noted both the connection between the requirement and the job, and the inability to perform the job without fulfilling that basic function (Rubbermaid Canada Inc. v Canadian Auto Workers, Local 252 (Order Picker Grievance), [2009] OLAA No. 639). The necessary connection between testing and job performance remains the lasting legacy of Meiorin. Without using the terminology explicitly, Meiorin challenges the use of most forms of construct validation testing as fundamentally inadequate in the context of a commitment to workplace diversity and human rights. This is not to argue that physical testing for employment should play no role in 
maintaining safe workplaces. As the Alberta Court of Appeal puts it, "Extending human rights protections to situations resulting in placing the lives of others at risk flies in the face of logic" (Alberta (Human Rights and Citizenship Commission) v Kellogg Brown \& Root (Canada) Co., 2007 ABCA 426, para 36). And yet it is equally important not to be overly persuaded by every argument invoking personal and public safety. Recall one of the fundamental missteps in Meiorin was in transplanting the recommendation that loggers be fit and trained in order to battle forest fires into a particular running standard that did not bear a sufficiently demonstrable relationship to Tawney Meiorin's actual job requirements, or take into account her satisfactory performance of the job. No one would question the assertion that fire fighters should be physically capable of handling the demands of the position. The question as a matter of human rights law is whether the particular physical standard employed to determine minimum fitness is demonstrably justifiable.

Rather than placing equality concerns and safety in tension with one another, as much of the case law and literature appears to assume, I think it better to approach both workplace safety and workplace equality concerns as emanating from the same basic commitment to the individual worth and dignity of each person. To that end, physical standards for employment related to specific aspects of the job which protect individuals from harm equally reflects and embodies human rights values to security of the person. In short, an unsafe workplace disregards the human rights of its workers and the public by placing persons unnecessarily in harm's way. But human rights are also promoted by a diverse workplace in which differently abled individuals are able to bring their unique skills and perspectives to work, including ideas about how a job might be performed in different and perhaps even safer ways for everyone. Properly 
calibrated, and equally respected, the interaction of physical standards for employment and human rights law achieve both human rights goals - security and diversity in the workplace.

\section{Conclusions}

In seeking the best practices of physical standards for employment it will be incumbent on test designers and employers alike to be mindful of the human rights implications of the design, implementation, and use of such testing. The modern generous and liberal approach to interpreting human rights legislation exhibited across the common law world, and the wide array of grounds of discrimination such legislation covers, especially sex, physical disability, and age, means that physical standards for employment will continue to face legal challenge. To the extent that physical standards for employment test skills related to strength, speed, or endurance, arbitrators and courts will likely continue to find that such testing prima facie discriminates on the basis of systemic physiological differences and physical capacities between majority participants and individuals falling within protected grounds of discrimination. To survive such scrutiny, physical employment testing will need to qualify as bona fide occupational requirements by satisfying a framework of justification, whether established by Meiorin, or another similar legislative and jurisprudential context. Whatever the national setting, physical standards for employment will need to be rationally connected to the job, and devised and implemented in good faith. Most crucially, physical standards for employment will need to be defended as reasonably necessary to the safe and efficient performance of the job. Accordingly, employers should employ standards, tests, and cut-off scores that adequately capture the minimum requirements to do a job safely and efficiently. This is generally best achieved with tests derived from a cross-section of actual satisfactory job performers which rely on criterion validation (actual job specific skills evaluated against a specific set of defensible criteria), as 
opposed to construct validation. Equally important will be an employer's processes for considering the accommodation of employees unable to meet the required standards. Courts have not held employers to an impossible standard to find work for everyone in all circumstances, but a demonstrated process of reasonable and reasoned deliberation that results in specific reasons why accommodation will pose undue hardship will satisfy a court, tribunal or arbitrator more readily than a blanket appeal to workplace safety.

Like so many areas of the law, the legality of physical standards for employment comes down to a question of balance. Legislative language may assist to guide that balance, but, ultimately, where judges, arbitrators, and human rights commissions draw lines between lawful and discriminatory physical testing standards will depend as much on the surrounding human rights culture and its judicial acceptance as the precise wording of formal legal enactments. Accordingly, conceptually similar legal regimes may yield entirely different outcomes in similar cases involving physical standards. That said, this article's review of several common law human rights regimes reveals a relative convergence of the operating concepts at work, despite the differences in the language in which those concepts are expressed. There is likely little difference between concepts like adverse effects and adverse impacts discrimination, a bona fide occupational qualification and a bona fide occupational requirement, reasonable accommodation and reasonable adjustment. What can be said with confidence is that lawmakers around the world appear driven by a strong desire to state the same legal principle slightly differently. And yet it is equally clear that, in the main, the United States, Canada, the United Kingdom, and Australia have developed human rights structures in unacknowledged influence of one another. In their own ways, each strives to find the appropriate balance between recognizing the human rights 
values of a workplace free from discrimination with the reality that some forms of work require some physical abilities that all people do not equally share.

I hope it is more than national familiarity, however, that leads me to prefer much of the Canadian approach. Although highly attentive to the importance of work in individual's lives, and generally protective of human rights values in the workplace, Canadian tribunals, courts, and arbitrators have accepted the legitimacy and efficacy of physical standards for employment in workplaces imposing physical demands. They have done so, however, by stipulating that to the extent such physical standards discriminate against groups of individuals with systemic physiological differences, they must be justified as minimally necessary for the safe and efficient performance of the job in question. This inquiry is performed in assessing whether or not the physical standard represents a bona fide occupational requirement: an employer's focus, in good faith, not on the particular individual's qualifications or capacities, but rather what the job requirements actually are. In addition, the concept of reasonable accommodations, as opposed to adjustments, better captures the essence of a duty that should involve some compromise (to the point of undue hardship) on the employer's part when considering how alternative techniques or equipment might reduce physical demands while protecting the fundamental aspects of job completion and safety. Together, the mutual functioning of a bona fide occupational requirement and the duty to accommodate actively promotes the societal commitment to build conceptions of equality into the workplace by placing a culture of justification and reason on employment decisions with otherwise potentially discriminatory impact.

Judge Charles Sifton took precisely that lesson from his experience serving as a judge in the American Berkman litigation concerning discriminatory firefighter testing. "I am in favor of diversity," he reflected after the case had concluded, 
I think it is beneficial to everyone involved. Diversity brings to bear different perspectives on things that may not occur to people in a homogeneous society.....Lightening the Scott's airpack made the job easier for men and women; made it possible for men who might have failed the physical test even though they passed the mental test with flying colors to pass both parts of the test and qualify for a job that otherwise they might have lost. Fire is a force that can overwhelm the strongest as well as the weaker....Having the women firefighters force all of us to focus on the real physical requirements of the job and on alternatives with less adverse impact was a wonderful thing (Landy 2005, p. 534).

Perhaps ironically, the greatest contribution of the interaction of human rights law and physical standards for employment may be in transforming for the better the ways in which work is performed, not by screening people out, but by letting them in. 


\section{Works Cited}

Adams, E.M. 2009. The Idea of Constitutional Rights and the Transformation of Canadian Constitutional Law, 1930-1960. SJD Thesis, University of Toronto (unpublished).

Adams, E.M. 2012. Errors of Fact and Law: Race, Space, and Hockey in Christie v York. UTLJ 62(4): 463-498.

Age Discrimination Act 2004, Australia (Cth)

Alberta Human Rights Act, RSA 2000, c A-25.5.

Alberta (Human Rights and Citizenship Commission) v Kellogg Brown \& Root (Canada) Co. (2007) ABCA 426.

Americans With Disabilities Act of 1990. Pub L 101-336, 104 Stat 328 (1990).

Andrews v Law Society of British Columbia (1989) 1 SCR 143.

Atiyah, P.S. 1979. The Rise and Fall of Freedom of Contract. Clarendon Press, Oxford.

Backhouse, C. 1999. 'Mesalliances' and the 'Menace to White Women's Virtue': Yee Clun's Opposition to the White Women's Labour Law, Saskatchewan, 1924. In Colour-Coded: A Legal History of Racism in Canada, 1900-1950. The Osgoode Society for Canadian Legal History, Toronto. pp. 132-172.

Barr v Treasury Board (Department of National Defence) [2006] PSLRB 85.

Beck, J.H., Reitz, J.G. and Weiner, N. 2002. Addressing Systemic Racial Discrimination in Employment: the Health Canada Case and Implications of Legislative Change. Canadian Public Policy 28(3): 373-394.

Berkman v City of New York(1982) 536 F Supp 177.

Bhasin v Hrynew [2014] 3 SCR 494.

Bolan, K 2000, “One of British Columbia's largest forestry companies has agreed to change its hiring practice to give a better chance to women who apply to work in its sawmills", Vancouver Sun 3 March, p. A7.

British Columbia Human Rights Act, RSBC 1996, c 210.

British Columbia (Public Service Employee Relations Commission v British Columbia Government and Service Employees' Union (Meiorin Grievance) (1996) BCCA No 441.

British Columbia (Public Service Employee Relations Commission v British Columbia Government and Service Employees' Union (Meiorin Grievance) (1997) 9 WWR 759 (BCCA). 
British Columbia (Public Service Employee Relations Commission v British Columbia Government and Service Employees' Union (B.C.G.S.E.U.) (Meiorin Grievance) [1999] 3 SCR 3.

British Columbia (Public Service Employee Relations Commission v British Columbia

Government and Service Employees' Union (B.C.G.S.E.U.) (Meiorin Grievance) (1999) 3 SCR 3 (Respondent's Amended Factum File No. 26274).

Buttle, J 1991, "Forest fire that claimed Sechelt man under control as mop-up continues", Vancouver Sun 3 August, p. A7.

Canada Labour Code, RSC 1985, c L-2.

Canadian Charter of Rights and Freedoms, Part I of the Constitution Act, 1982, being Schedule B to the Canada Act 1982 (UK), 1982, c 11.

Canadian Human Rights Act, RSC 1985, c H-6.

Canadian Union of Public Employees, Local 4400 v Toronto District School Board (Shaw Grievance) (2003) OLAA No 514.

Central Dairy Pool v Alberta (Human Rights Commission [1990] 2 SCR 489.

Christie v York [1940] SCR 139.

Civil Rights Act of $1964 \S 7,42$ USC $\S 2000$ e et seq (1964).

The Civil Rights Act of 1991, 42 USC $§ 2000 \mathrm{e}-2(\mathrm{k})(2000)$.

Clément, D. 2008. Canada's Rights Revolution: Social Movements and Social Change, 1937-82. UBC Press, Vancouver.

Clément, D. 2014. Equality Deferred: Sex Discrimination and British Columbia's Human Rights State, 1953-1984. The Osgoode Society for Canadian Legal History, Vancouver.

Constitution Act, 1867 (UK), 30 \& 31 Vict. C 3, reprinted in RSC 1985, App II, No 5.

Cox, R., and Messing, K. 2006. Legal and Biological Perspectives on Employment Testing for Physical Abilities: A Post-Meiorin Review. 24 Windsor YB Access Just. 23.

Criminal Code, RSC 1985, c C-46.

Devlin, D.A., 1991. Circumstances as a Result of the Inquiry. 29 November. File No. 91-302-00. Disability Discrimination Act 1992, Australia (Cth).

The Discrimination Act 1992, Australia (Cth). 
Discrimination at Work: Employment Law Handbook 2012, Thomson Reuters, London.

Dothard v Rawlison (1975) 433 US 321.

Eldridge v British Columbia (Attorney General) [1997] 3 SCR 624.

Employment Discrimination Litigation: Behavioral, Quantitative, and Legal Perspectives. Edited by F. J. Landy. 2005. Jossey Bass, San Francisco. pp. 523-

Employment Standards, RSA 2000, c E-9.

Equality Act 2010 (UK), c 15.

Evans v City of Evanston (1989) 881 F (2d) 382.

The Fair Employment Practices Act, SO 1951, c 24.

"Forest fire claims life" The Sunshine Coast News 5 August 1991, p.1.

Frager, R.A. and Patrias, C. 2005. Discounted Labour: Women Workers in Canada, 1870-1939. University of Toronto Press, Toronto.

Fraser, K 1991, "Blaze Claims Logger: Inlet Fire 'Came Right at Them and They All Took Off Running"” The Province 2 August, p. 1.

Fudge, J. and Lessard, H. 2010. Challenging Norms and Creating Precedents: The Tale of a Woman Firefighter in the Forests of British Columbia. In Work on Trial: Canadian Labour Law Struggles. Edited by J. Fudge and E. Tucker. The Osgoode Society for Canadian Legal History, Toronto, pp. 315-

Gall, P.A. and Chapman, S. 2012. Legislation by Litigation: Individualized Accommodation in the Workplace. 59 SCLR (2d) 381.

Gillis, A.D. and Darby, B. 2001. To serve and protect, post Meiorin. In Proceedings of the Consensus Forum on Establishing Bona Fide Requirements for Physically Demanding Occupations. Edited by N. Gledhill, J. Bonneau, and A. Salmon. Toronto. pp. 85-

Gledhill, N. and Bonneau, J. Objectives, Process and Consensus Summary of the National Forum on Bona Fide Occupational Requirements. In: Proceedings of the Consensus Forum on Establishing BONA FIDE Requirements for Physically Demanding Occupations. Ed: N.

Gledhill, J. Bonneau and A. Salmon. Toronto, Chapter 1, 2001.

Griggs v Duke Power Co. (1971) 401 US 424. 
Guthrie, R. and Westaway, J. 2009. Emerging legal concerns with chronic diseases in the Australian workplace: Pre-employment medicals, functional capacity evaluations, workers' compensation and disability discrimination. 16 JLM 803.

Howe, R. B. and Johnson, D. 2000. Restraining Equality: Human Rights Commissions in Canada. University of Toronto Press, Toronto.

Human Rights Act, CCSM c H175.

Human Rights Act, SA 1966, c 39.

Human Rights Act, SBC 1969, c 10.

Human Rights Code, RSO 1990, c H 19.

Hydro-Québec v Syndicat des employé-e-s de techniques professionnelles et de bureau d'HydroQuebec, section locale 2000 (SCFP-FTQ) (2008) 2 SCR 561.

Jackson, B 1991, “Man dies fighting Sechelt forest fire”, Vancouver Sun 2 August, p. A1.

Labour Relations Code, RSA 2000, c L-1.

Lanning v Southeastern Pennsylvania Transportation Authority (SEPTA) (1999) 181 F (3d) 478 (3d Cir 1999).

Lanning v Southeastern Pennsylvania Transportation Authority (2002) 308 F (3d) 289, (3d Circ 2002).

Lindemann, B. T. and Grossman, P. 2007. Adverse Impact. In Employment Discrimination Law, 4th edn, vol 1. BNA Books, Washington, DC, p. 109.

Lindemann, B.T. and Grossman, P. 2007. Employment Discrimination Law, 4th edn, vol 1. BNA Books, Washington DC.

Lynk, M. 2002. Disability and the Duty to Accommodate: An Arbitrator's Perspective. In Labour Arbitration Yearbook 2001-2002. Lancaster House, Toronto. 51-

Machtinger v HOJ Industries Ltd [1992] 1 SCR 986.

Miller Jr., R.S. 1966-1967. Sex Discrimination and Title VII of the Civil Rights Act of 1964.

Minn L Rev 51(5): 877-897.

Moore v British Columbia [2012] 3 SCR 360.

Morehead v New York ex rel. Tipaldo, 298 US 587 (1936).

Northern Telecom Ltd. V. Communications Workers of Canada [1980] 15 SCR 115. 
Nova Scotia Human Rights Act, RSNS 1989, c 214.

Occupational Health and Safety Act, RSA 2000, c O-2.

The Ontario Human Rights Code, SO 1961-62, c 93.

Ontario (Human Rights Commission) v Borough of Etobicoke [1982] 1 SCR 202.

Ontario Human Rights Commission and O'Malley v Simspons-Sears [1985] 2 SCR 536.

Patrias, C. 2007. Race, Employment Discrimination, and State Complicity in Wartime Canada, 1939-1945. Labour/Le Travail 59: 9-41.

Pothier, Dianne. 2010-2011. Tackling Disability Discrimination at Work: Toward a Systemic Approach. McGill JL \& Health 4: 18-37.

Qantas Airways v Christie [1998] HCA 18.

$R v$ Kazenelson, 2016 ONSC 25

Racial Discrimination Act, SO 1944, c 51.

Racial Discrimination Act 1975, Australia (Cth).

Raytheon Co v Hernandez (2003) 540 US 44.

Reference re Public Service Employee Relations Act (Alta.) [1987] 1 SCR 313.

Reitz, J.G. and Banerjee, R. 2007. Racial Inequality, Social Cohesion and Policy Issues in Canada" In Belonging? Diversity, Recognition and Shared Citizenship in Canada. Edited by K. G. Banting, T. J. Courchene and F. L. Seidle. McGill-Queen's University Press, Montreal. pp. 489-

Roberts, D, et. al. 2016. Sex Related Issues in Physical Employment Standards. Applied Physiology, Nutrition, and Metabolism.

Ronalds, C. and Raper, E. 2012. Discrimination Law and Practice, 4th edn, Federation Press, Sydney.

Rubbermaid Canada Inc. v Canadian Auto Workers, Local 252 (Order Picker Grievance) (2009) OLAA No 639.

Rutherglen, G. 2010. Employment Discrimination Law: Visions of Equality in Theory and Doctrine, 3rd edn, Foundation Press, New York.

Saskatchewan Bill of Rights, SS 1947, c 35. 
Sex Discrimination Act 1984, Australia (Cth).

Sheppard C. 2000-2001. Of Forest Fires and Systemic Discrimination: A Review of British Columbia (Public Service Employee Relations Commission) v. B.C.G.S.E.U. McGill LJ 46(2): 533-559.

Tarnopolsky, W. S. 1982. Discrimination and the Law in Canada. Richard De Boo, Toronto. Uniform Guidelines on Employee Selection Procedures. 29 CFR Part 1607 (1978).

United Auto Workers v Johnson Controls Inc (1991) 499 US 187.

University of British Columbia v Berg (1993) 2 SCR 353.

Wards Cove Packing Co. v Antonio (1989) 490 US 642.

Xv Commonwealth of Australia [1999] HCA 63.

Zaromitidis v Toronto Police Service Board and HMQ in Right of Ontario (Minister of Community Safety and Correctional Services) (2014) HRTO 1296.

Zumbo, Bruno. 2016. Standard-setting methodology: Establishing performance standards and setting cut scores to assist score interpretation. Applied Physiology, Nutrition, and Metabolism. 